\title{
"Efficient use of the insurance sector potential adjusted for its shadowing: Case of Ukraine"
}

\begin{tabular}{|c|c|}
\hline AUTHORS & $\begin{array}{l}\text { Mariana Melnyk (iD) } \\
\text { Olha Zhabynets (iD) } \\
\text { Ivanna Myshchyshyn (D) } \\
\text { Volodymyr Orlov (iD) }\end{array}$ \\
\hline ARTICLE INFO & $\begin{array}{l}\text { Mariana Melnyk, Olha Zhabynets, Ivanna Myshchyshyn and Volodymyr Orlov } \\
\text { (2021). Efficient use of the insurance sector potential adjusted for its shadowing: } \\
\text { Case of Ukraine. Insurance Markets and Companies, 12(1), 16-31. } \\
\text { doi:10.21511/ins.12(1).2021.02 }\end{array}$ \\
\hline DOI & http://dx.doi.org/10.21511/ins.12(1).2021.02 \\
\hline RELEASED ON & Thursday, 11 February 2021 \\
\hline RECEIVED ON & Saturday, 21 November 2020 \\
\hline ACCEPTED ON & Monday, 25 January 2021 \\
\hline LICENSE & $\begin{array}{l}(c) \text { EY } \\
\text { This work is licensed under a Creative Commons Attribution } 4.0 \text { International } \\
\text { License }\end{array}$ \\
\hline JOURNAL & "Insurance Markets and Companies" \\
\hline ISSN PRINT & $2616-3551$ \\
\hline ISSN ONLINE & $2522-9591$ \\
\hline PUBLISHER & LLC "Consulting Publishing Company "Business Perspectives" \\
\hline FOUNDER & LLC "Consulting Publishing Company "Business Perspectives" \\
\hline
\end{tabular}

NUMBER OF REFERENCES

48

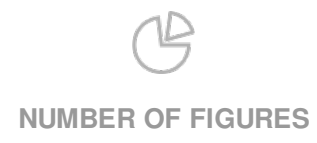

4

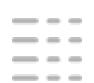

NUMBER OF TABLES

5

(C) The author(s) 2022. This publication is an open access article. 


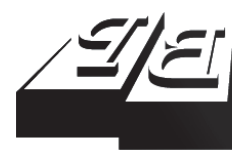

\section{BUSINESS PERSPECTIVES}

(2)

LLC "CPC "Business Perspectives" Hryhorii Skovoroda lane, 10, Sumy, 40022, Ukraine www.businessperspectives.org
Received on: $21^{\text {st }}$ of November, 2020 Accepted on: $25^{\text {th }}$ of January, 2021 Published on: $11^{\text {th }}$ of February, 2021

() Mariana Melnyk, Olha Zhabynets, Ivanna Myshchyshyn, Volodymyr Orlov, 2021

Mariana Melnyk, Doctor of Economics, Professor, State Institution "Institute of Regional Research Named after M.I. Dolishniy of the NAS of Ukraine", Ukraine.

Olha Zhabynets, Ph.D. in Economics, Associate Professor, State Institution "Institute of Regional Research Named after M.I. Dolishniy of the NAS of

Ukraine", Ukraine. (Corresponding author)

Ivanna Myshchyshyn, Junior Reseacher, State Institution "Institute of Regional Research Named after M.I. Dolishniy of the NAS of Ukraine", Ukraine.

Volodymyr Orlov, Head of Department, Asset Recovery and Management Agency, Ukraine.
Mariana Melnyk (Ukraine), Olha Zhabynets (Ukraine), Ivanna Myshchyshyn (Ukraine), Volodymyr Orlov (Ukraine)

\section{EFFICIENT USE OF THE} INSURANCE SECTOR POTENTIAL ADJUSTED FOR ITS SHADOWING: CASE OF UKRAINE

\begin{abstract}
The insurance sector plays a critical role in the economy, providing protection and security of the state and influencing its social and economic development. However, having a significant potential for development, the sector cannot fully realize it due to many problems, including its shadowing. Using the method of unprofitable enterprises analysis, which is applied by the Ministry for Development of Economy, Trade and Agriculture of Ukraine to determine the level of the shadow economy, considering the type of economic activity, the level of shadowing of the insurance services sector in Ukraine and its regions in 2013 and 2018 was calculated. The calculation results showed an increase in the shadow level of the insurance services sector both in Ukraine as a whole and in the separate regions. To evaluate the effectiveness of the insurance sector potential, given the calculated level of shadowing, a comprehensive assessment was carried out by standardizing the values of selected indicators characterizing the potential of the insurance sector in the context of Ukraine's socio-economic development. The indicators of the efficient use of the insurance services sector potential in Ukrainian regions, calculated using an integrated assessment, showed an increase in the efficiency of using the potential of the insurance sector in three out of five analyzed regions. Zaporizhzhia region demonstrated the most significant growth. It has been proven that an increase in the volume of services provided is a key factor in increasing the social and economic efficiency of the insurance sector
\end{abstract}

\section{Keywords}

potential for development, integrated index, insurance services sector, social and economic development, regions of Ukraine

\section{JEL Classification G22, G23, R11}

\section{INTRODUCTION}

The sector of insurance, reinsurance and private pension provision ${ }^{1}$ (hereinafter - the insurance services sector) plays an important role in the economy, ensuring the protection and security of the state and influencing the level of its social and economic development. In Ukraine, the insurance services sector is represented by insurance companies and non-state pension funds (hereinafter - NPFs). The latter, together with life insurance companies, provide services to the population within the framework of the non-state pension system. The importance of the insurance services sector is growing not only in view of its contribution to the formation of the third pillar of Ukraine's pension system, but also in the context of today's global coronavirus pandemic, when most citizens are left alone with this problem and need insurance coverage. It should be noted that insurance companies (non-life insurance companies) promptly responded to the needs of society and

1 According to the Classifier of Economic Activities 2010: Section 65 "Insurance, reinsurance and private pension provision, except for compulsory social insurance" includes underwriting of annuities, insurance policies and insurance premiums in order to create financial assets that will be used to repay future insurance claims. This section includes direct insurance and reinsurance. 
already today offer many insurance protection programs against COVID-19, including when traveling abroad (when buying a travel insurance policy). In addition, the Verkhovna Rada of Ukraine registered a Draft Law on Amendments to the Law of Ukraine On Tourism (Legislation of Ukraine, 2020). This draft law proposes to introduce compulsory insurance for the return of our tourists to Ukraine and payment for their accommodation and meals during forced stay abroad, which is especially relevant given the tourism risks posed by COVID-19. At the same time, possessing significant development potential, Ukrainian insurance companies cannot fully implement it due to many problems; one of the key problems is the shadowing. Unfortunately, at the national level, shadowing is assessed only in general for Financial and Insurance Activities, and the problems of shadowing and assessing its level in the insurance services sector as one of the key in this type of economic activity remain practically unexplored, which determines the relevance of this study.

\section{LITERATURE REVIEW}

Nowadays, shadowing of Ukraine's economy are the subject of research by many Ukrainian and foreign scientists. In particular, Shumska and Nezhyvenko (2013) considered methodological approaches to determining the size of the shadow economy in Ukraine and the world and assessing its level by various methods. Vinnychuk and Ziukov (2013) and Levchenko et al. (2019) built an economic and mathematical model to identify patterns of the shadow economy. Remeikiene et al. (2017) studied the influence of the main factors on the shadowing of Ukraine's economy using regression analysis. Gamankova (2009) and Zhabynets (2020) examined the main shadow financial schemes in the context of the insurance market development. Vasylenko (2012) and Kravets (2007) analyzed the features and methods of scheme insurance, as well as the main characteristics indicating the level of its penetration in the Ukrainian insurance market. Boyko and Roienko (2015) analyzed the most common illegal schemes for using the services of insurance companies to minimize the tax burden and legalize proceeds of crime. Schwarcz (2015) investigated the risks associated with shadow insurance operations in the US insurance market, including in the context of the effectiveness of government regulation. Koijen and Yogo (2016) studied shadow reinsurance in life insurance, and Hepfer et al. (2016) considered shadow insurance as a tool for tax optimization and increasing additional payments to shareholders.

In Ukraine, very few scientific publications are devoted to scientific problems of the formation and use of the insurance sector potential. Likhonosova
(2020) and Romanovska et al. (2020) are among the recent studies on the issue (2020). Most studies by domestic researchers analyze the potential of insurance companies (financial, investment, competitive, etc.) and the potential for the development of certain types of insurance services (Ionin, 2017; Samorodov et al., 2018; Kovalenko \& Litvin, 2019; Vilenchuk, 2017). With regard to foreign scientific publications, Jarrayaa and Bourib (2013) reviewed methods for assessing efficiency in the insurance industry, Vucetich et al. (2014) analyzed the role of the insurance services sector in driving economic development and assessed its potential for the New Zealand economy, Domański et al. (2020) revealed the prospects for using the potential of the Polish insurance sector in providing services to small and medium-sized businesses.

\section{AIMS}

The paper is aimed at assessing the effectiveness of using the insurance services sector potential, taking into account its shadowing, in providing the social and economic development of Ukraine and its regions.

\section{METHODS}

The basis for calculating the level of shadowing of the insurance services sector was the methodology of unprofitable enterprises in accordance with the Guidelines for Calculating the Level of the Shadow Economy, approved by the Order of the Ministry for Development of Economy, Trade and Agriculture of Ukraine No. 123 dated February 18, 2009 (Ministry for Development of Economy, 
Trade and Agriculture of Ukraine, 2009). The Ministry of Economic Development, Trade and Agriculture of Ukraine calculates shadowing by type of economic activity as a percentage to GVA of the corresponding type. Since GVA is not generated for the analyzed sector (this is described below in the methodology), the calculations were carried out using the GVA of foreign economic activity "Financial and Insurance Activities". This is the author's approach based on the methodology of the Ministry.

The following assumptions were used when applying this method:

1) according to official statistics, all unprofitable enterprises are actually profitable, which is considered an overstatement of the shadow economy; the profitability of unprofitable enterprises equals the profitability of profitable enterprises in the analyzed period;

2) the ratio of costs of unprofitable and profitable enterprises is identical to the ratio of the number of such enterprises.

The attributable profit of unprofitable enterprises in the analyzed period $\left(P_{U E c t}\right)$ is calculated using the following formula:

$$
P_{U E c t}=P B T_{P E t} \cdot \frac{N_{U E t}}{N_{P E t}},
$$

where $P B T_{P E t}$ is the before-tax financial result of profitable enterprises (profit) in the analyzed period, according to the official statistics (thousand $\mathrm{UAH}$ ); $N_{U E t}$ is the number of unprofitable enterprises in the analyzed period, according to the official statistics (units); and $N_{P E t}$ is the number of profitable enterprises in the analyzed period, according to the official statistics (units).

Shadow profit in the period under analysis $\left(P s_{t}\right)$ is calculated using the following formula:

$$
P_{S t}=P_{U E c t}+P B T_{U E t},
$$

where $P_{U E c t}$ is attributable profit of unprofitable enterprises in the analyzed period (thousand UAH); $P B T_{U E t}$ is the financial result before tax of unprofitable enterprises (loss) in the analyzed period, according to the official statistics (thousand UAH).
The marginal minimum level of the shadow economy $\left(R_{\text {SE min }}\right)$ is calculated taking into account the above assumptions using the following formula:

$$
R_{S E \min t}=\frac{P_{S t}}{G V A_{t}} \cdot 100,
$$

where $P_{s t}$ is shadow profit in the analyzed period (thousand UAH); GVA is the volume of gross value added (GVA) for the corresponding type of economic activity in the analyzed period (thousand UAH).

Since the State Statistics Service of Ukraine does not generate information on GVA by type of economic activity Insurance, Reinsurance and Private Pension Provision, Except for Compulsory Social Insurance (code 65), the amount of GVA for Financial and Insurance Activities is used for calculations.

The marginal maximum level of the shadow economy $\left(R_{S E \text { max }}\right)$ is calculated on the assumption that all profitable enterprises provide only undistorted data, and all unprofitable enterprises hide the entire GVA of their products, and not only profits. In this case, the marginal maximum level of the shadow economy is calculated using the following formula:

$$
R_{S E \max t}=\frac{N_{U E t}}{N_{P E t}+N_{U E t}} \cdot 100 .
$$

The average value of the shadow economy $\left(R_{\text {SE aver }}\right)$ is calculated as follows:

$$
R_{S E \text { aver } t}=\left(R_{S E \max t}+R_{S E \min t}\right) / 2 .
$$

The integrated index of the efficiency of using the insurance services sector potential in providing the socio-economic development of Ukrainian regions was calculated by standardizing the values of the selected indicators relative to the reference value. To calculate the potential of the insurance services sector in the context of socio-economic development of Ukraine's regions, the following indicators were used: shadowing level, the share by volume of services provided in the service sector, the share by volume of services provided in the region, the share by employment in the services sector, the share by employment in the region, the share by capital investments in the services sector, the share by capital investments in the region, the enterprises' financial 
result before tax, the share of profitable enterprises in the sector, the amount of taxes paid by enterprises in the sector, the share in the amount of taxes paid in the region, and labor productivity. Among the selected indicators, only one is a deterrent (shadowing level), the rest are stimulants.

The selected indicators relative to the reference value are standardized using the following formulas:

3) for stimulants:

$$
N_{i j}=100-\frac{Z_{i j}}{Z i_{\max }} \cdot 100
$$

4) for the deterrent:

$$
N_{i j}=100-\frac{Z i_{\min }}{Z_{i j}} \cdot 100,
$$

where $N_{i j}$ is the standardized value of the $i$-th indicator of the $j$-th region; $Z_{i j}$ is the value of the $i$-th indicator in the $j$-th region; $Z i_{\text {max }}$ is the maximum value of the $i$-th indicator among all regions; $Z i_{\min }$ is the minimum value of the $i$-th indicator among all regions.

The integrated index of the efficiency of using the insurance sector potential in providing a region's socio-economic development $\left(I_{\text {ntegral } j}\right)$ is calculated as follows:

$$
I_{\text {integral }_{j}}=\left(100-\frac{\sum_{i=1}^{n} N_{i j}}{n}\right) / 100,
$$

where $N_{i j}$ are standardized values of the $j$-th region; $n$ is the number of standardized indicators of the $j$-th region.

The numerical range Integral $j$ is within [0: 1$]$. According to the chosen methodology, the higher value of the integrated index will indicate a more efficient use of the insurance services sector potential in providing the socio-economic development of Ukrainian regions.

\section{RESULTS}

The insurance services sector provides insurance capital in the form of insurance premiums
(Kozmenko \& Roienko, 2013; Zhabynets, 2014; Kaigorodova et al., 2018) paid for the sale of insurance liabilities (insurance services) (Arkhipov et al., 2017; Pyrkova et al., 2020). In 2013-2018, the development of the insurance services sector is characterized by an annual decrease in the number of operating enterprises (see Figure 1). Despite this, the volumes of services sold (after a slight reduction in 2014) demonstrate stable growth (total growth in 2013-2018 amounted to 41.03\%). After the 2014-2015 crisis, there has also been an increase in the assets of enterprises in the sector. In terms of the volume of insurance premiums collected in currency equivalent in 2018, the Ukrainian insurance market ranked 60th in the world (61st in 2017), in terms of growth rates, as in the previous year, it entered the top 10 most dynamic markets of developing countries (Minfin, 2019). At the same time, many factors restrain the development of the sector. In particular, a number of insurance companies have problems with solvency and liquidity, there is no clear business model, and the level of risk management and corporate governance is low. All this makes the market non-transparent and non-competitive (National Bank of Ukraine, 2020). The situation in the activities of pension funds is even more critical (Baranovskyi et al., 2015; Kozmenko \& Mospanova, 2016). For five years (December 2013 to December 2018), the average annual net investment income (excluding service costs) was $9.6 \%$. During the same period, the average annual inflation reached $19.2 \%$. Thus, the NPF participants received on average negative net investment income (excluding costs for services and inflation) in the amount of $-8.1 \%$ per year. Such low performance of NPFs is explained by many reasons, namely: the unfavorable macroeconomic situation (Grzebyk \& Stec, 2014), lack of developed capital markets and reliable financial instruments, low income and a lack of understanding of the need to save up for pensions (Płonka et al., 2020), as well as insufficient promotion of the importance (even lack of information about the existence) of private pension schemes (USAID, 2019).

Comparison of the share of insurance services in commercial and financial services (Figure 2) shows that in 2018 the share of insurance services in the total volume of financial services provided in Ukraine accounted for almost a third of all 
Source: Built according to official requests to the State Statistics Service of Ukraine (2019).

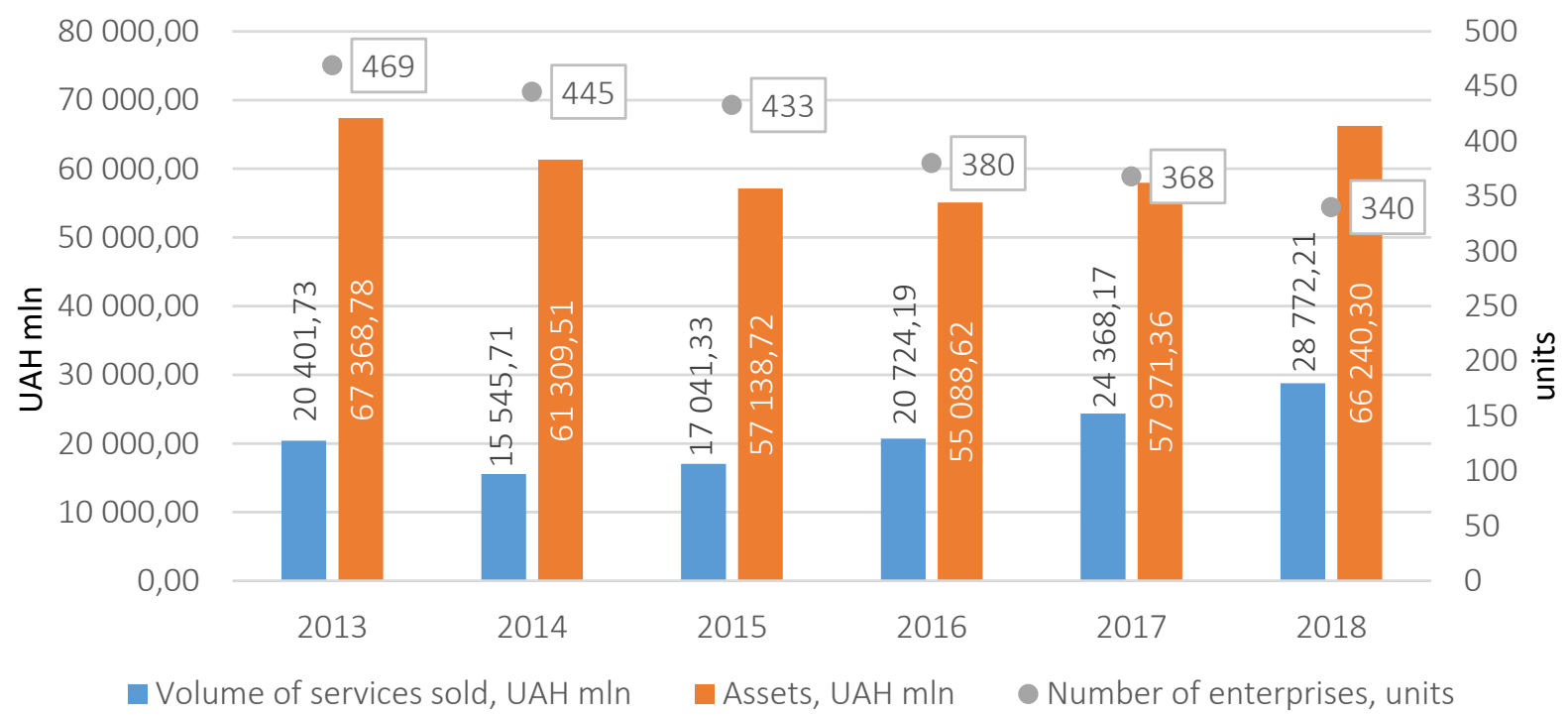

Figure 1. Development of the insurance services sector in Ukraine during 2013-2018

financial services rendered, and the share of in- Similar to the all-Ukrainian trend, a decrease is surance services in commercial services was only $3.72 \%$, and during the analyzed period there was a decrease in this share by almost 2 percentage points. observed in the share of insurance services in commercial services in all analyzed regions, except for Zaporizhzhia region. This is due to a sharp reduction in these regions (in 2018 compared to 2013) in

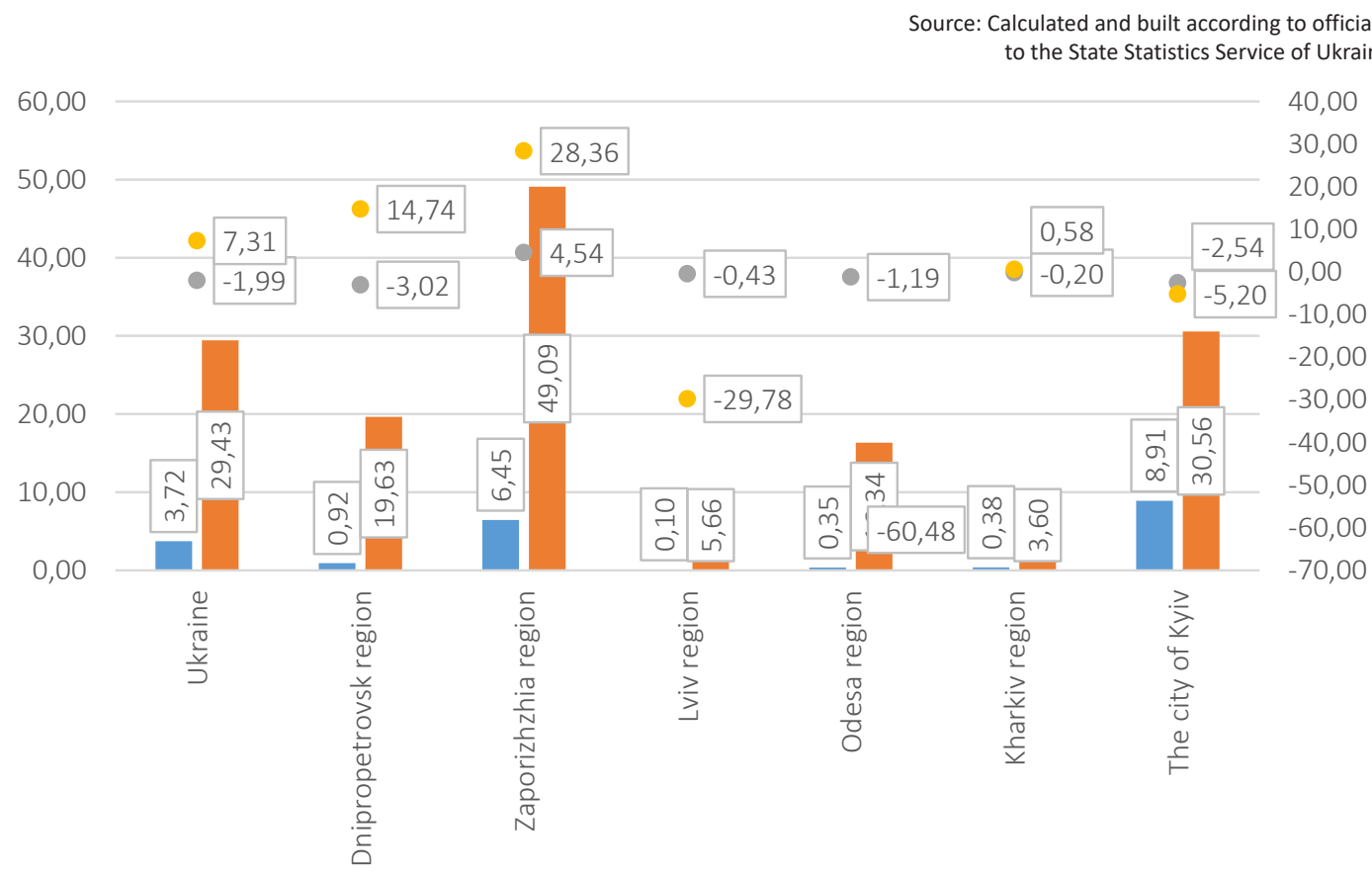

- Share of insurance services in commercial services, \%

n Share of insurance services in financial services, \%

- Changing the share of insurance services in commercial services, p.p.

- Changing the share of insurance services in financial services, p.p.

Figure 2. The share of insurance services in the total volume of provided commercial and financial services in 2018 (left scale) and its change in 2013-2018 (right scale) 
Table 1. Trends in the provision of insurance services in 2013-2018 in Ukraine and regions

\begin{tabular}{|c|c|c|c|c|c|c|c|}
\hline \multirow{2}{*}{ Region } & \multicolumn{6}{|c|}{ Volume of services sold, UAH million } & \multirow{2}{*}{$\begin{array}{c}\text { Increase } \\
\text { (decrease) for } \\
2013-2018, \%\end{array}$} \\
\hline & 2013 & 2014 & 2015 & 2016 & 2017 & 2018 & \\
\hline Ukraine & $20,401.7$ & $15,545.7$ & $17,041.3$ & $20,724.2$ & $24,368.2$ & $28,772.2$ & 41.03 \\
\hline Dnipropetrovsk & 811.8 & 711.8 & 712.5 & 1443.6 & 956.0 & 551.8 & -32.03 \\
\hline Donetsk & $2,340.1$ & 583.0 & 254.8 & 291.4 & $1,137.9$ & C & n.a. \\
\hline Zaporizhzhia & 129.4 & 137.4 & 379.5 & 494.2 & C & 1017.7 & 686.55 \\
\hline Lviv & 80.2 & 66.5 & 33.6 & 39.8 & c & 41.0 & -48.92 \\
\hline Odesa & 451.1 & 174.7 & 147.7 & 179.0 & 211.7 & 243.3 & -46.07 \\
\hline Poltava & 341.5 & 431.5 & 213.1 & 78.4 & 82.3 & $\mathrm{C}$ & n.a. \\
\hline Kharkiv & 87.2 & 378.7 & 63.4 & 77.8 & C & 134.6 & 54.24 \\
\hline The city of Kyiv & $15,369.8$ & $12,815.9$ & $14,953.4$ & $17,762.3$ & $20,702.7$ & $25,498.2$ & 65.9 \\
\hline
\end{tabular}

Note: c - confidential information; n.a. - calculation is not possible due to lack of information.

the number of companies that provided insurance services.

The growth of the share of insurance services in the total volume of commercial and financial services in Zaporizhzhia region is due to the entry of a powerful insurance company ASKA into the market, which began its work in the early 90 s as a regional part of ASKO holding with headquarters in Donetsk. Because of the events in the east of Ukraine (2014-2015), the company moved to the territory controlled by Ukraine. The city of Zaporizhzhia is the place of state registration of the insurer. It should be noted that despite the loss of leading positions in the industry ratings, ASKA was able to maintain a qualified team and customer confidence. In the summer of 2017, the company makes the largest payment in the history of Ukrainian agricultural insurance - more than 2 million euros for the loss of soybeans in Bukovyna due to drought. In 2018, ASKA was the first in the Ukrainian market to provide the CASCO service on the principle of "pay as you drive" using modern technological solutions (ASKA, n.d.).

Table 1 shows the trends in the provision of insurance services in 2013-2018 in Ukraine and its regions.

Since 2015, a gradual but stable growth in the provision of insurance services has been observed in Ukraine, and the total increase in the volume of services rendered in 2018 compared to 2013 was more than $40 \%$. In terms of Ukraine's regions, in
2018 compared to 2013, there was a decrease in the volume of services provided in Dnipropetrovsk, Lviv and Odesa regions, and growth - in Zaporizhzhia and Kharkiv regions and the city of Kyiv. It is noteworthy that in terms of the intensity of changes and a significant increase in the volume of insurance services, the undisputed leader is the Zaporizhzhia region with an increase of almost $700 \%$.

The results of many scientific studies (Kravets, 2007; Gamankova, 2009; Vasylenko, 2012; Zhabynets, 2020) prove that Ukrainian insurance companies are actively involved in various shadow financial schemes (provision of tax optimization services for business; use of internal incoming reinsurance to reduce tax liabilities; withdrawal of funds outside Ukraine or cash transfer using technical securities), which contributes to the shadowing of both the insurance sector and the real sector of the Ukrainian economy.

In this study, the shadowing of the insurance services sector is understood as such financial and economic activities of enterprises in the sector, aimed at hiding income from business activities through various shadow financial schemes.

Using the methodology described above (see Formulas 1-5), the level of the shadow economy of the insurance services sector in Ukraine and its regions was calculated (Appendix A) based on statistical data on the financial performance of enterprises in the sector in 2013 and 2018. The limit- 


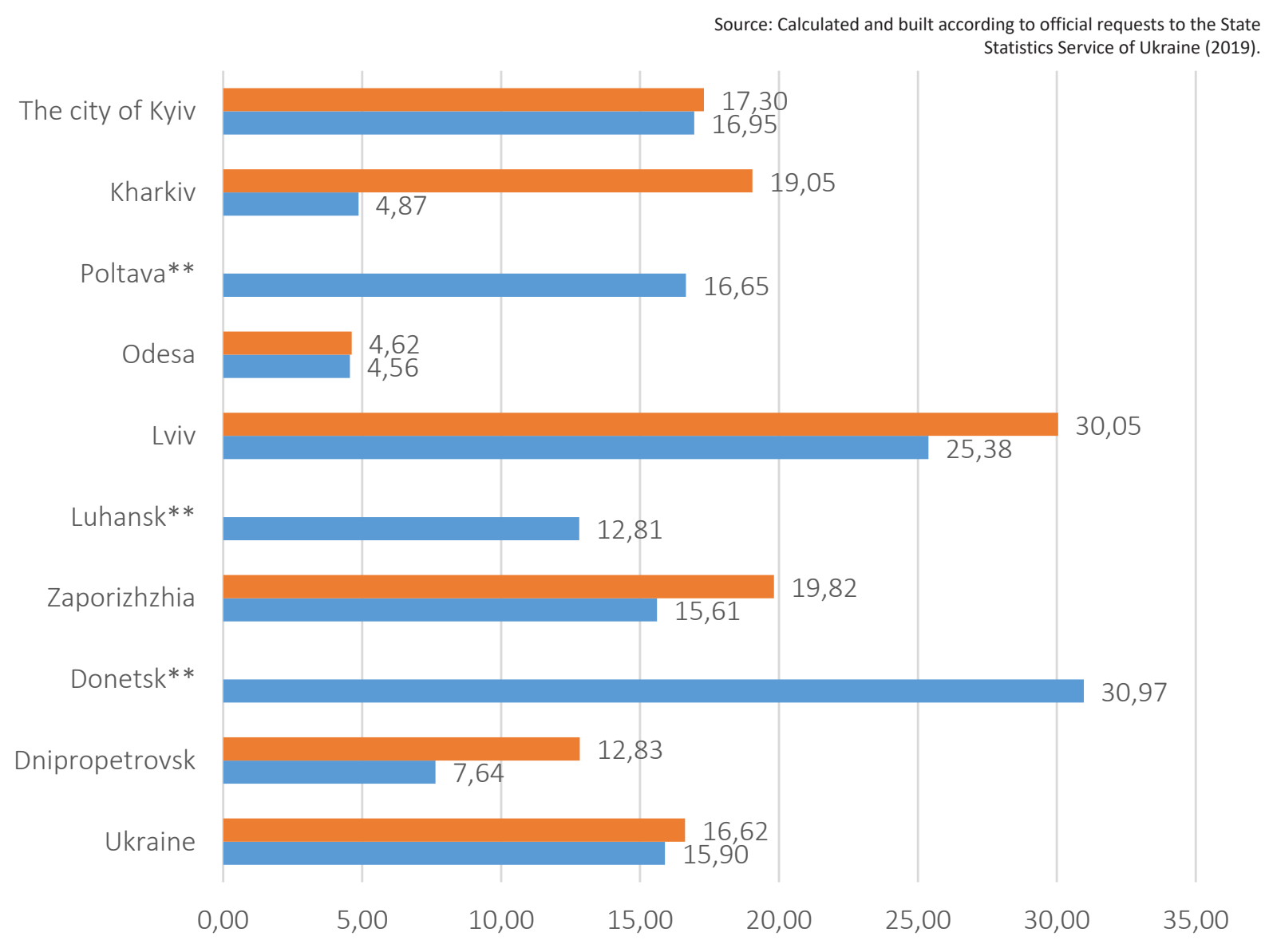

$2018 \square 2013$

Note: ${ }^{* *}$ - for these regions there was no information for making calculations in 2018.

Figure 3. The level of shadowing of the insurance services sector in Ukraine and its regions in 2013 and 2018 , \% of GVA of Financial and Insurance Activities

ed statistical information obtained from the State Statistics Service of Ukraine due to its confidentiality did not allow assessing the level of shadowing in the insurance services sector in all Ukrainian regions. As a result, the shadowing level was calculated for only nine regions in 2013 and six regions in 2018 (Figure 3).

Thus, in 2013-2018, the insurance services sector saw an increase in the level of shadowing in Ukraine as a whole and in the analyzed regions. The largest increase was recorded in the Kharkiv region (by 14.18 p.p.), the smallest - in the Odesa region (by only 0.06 p.p.). Such a significant increase in the level of shadowing of the insurance services sector in the Kharkiv region is explained by a decrease in the number of profitable enterprises during the analyzed period (from 19 to 10), as a result of which the value of shadow profit increased 3.3 times (see Appendix A).

The shadowing of the insurance services sector and the use of its opportunities for tax optimization by enterprises of the real economy sector are due to the following main reasons:

1. Crisis phenomena in the economy caused by political, financial or other factors (global financial crisis, military conflict in the east of Ukraine, global coronavirus pandemic, etc.) According to official data, in 2014, due to the military conflict in eastern Ukraine, the level of the shadow economy in Ukraine, calculated using the method of unprofitable enterprises, reached $35 \%$ of GDP, which was the highest value since 2010 (Ministry for Development of 
Economy, Trade and Agriculture of Ukraine, 2020); the introduction of quarantine restrictions due to the global coronavirus pandemic contributed to an increase in the level of shadowing of Ukraine's economy (using the method of unprofitable enterprises) in just three months of 2020 to $38 \%$ of GDP, which is 15 p.p. more than in three months of 2019 (Ministry for Development of Economy, Trade and Agriculture of Ukraine, 2020).

2. High level of corruption - According to the Corruption Perceptions Index in 2018, Ukraine ranked 120th out of 180 countries (Transparency International, 2018).

3. Unfavorable tax and regulatory policies in business (high tax burden, state overregulation of entrepreneurship, frequent changes in tax legislation, etc.) - In 2018, according to the Index of Economic Freedom, Ukraine ranked 150th out of 186 countries (Miller et al., 2018), according to the Ease of Doing Business Index - 71st out of 190 countries (World Bank, 2019).

4. The specificity of taxation of insurance companies (Legislation of Ukraine, 2010), in comparison with enterprises of other sectors, allows insurance companies to use incoming domestic reinsurance operations to reduce income tax.

5. Significant volumes of operations of insurance companies with securities in the context of underdeveloped domestic stock market - In terms of the Global Competitiveness Index components, according to the parameter "Financing through local equity market", Ukraine ranked 114th out of 137 countries, and according to "Regulation of securities exchanges", it was 134th out of 137 countries in terms of), that is, one of the five top world outsiders (Schwab, 2019).

Improving the efficiency and stability of the national economy, iraising the level of its socio-economic development is impossible without increasing the potential of the insurance sector. Based on available statistical data (according to Formulas 6-8), an integrated index of the efficiency of using the potential of the insurance services sector in ensuring the socio-economic growth of Ukraine's regions was calculated (Table 2) and its change for 2013-2018 was analyzed.

An increase in the efficiency of using the potential of the insurance services sector in providing the socio-economic growth of Ukraine's regions for 2013-2018 is observed in Dnipropetrovsk and Zaporizhzhia regions, as well as in the city of Kyiv. The largest growth was demonstrated by the Zaporizhzhia region, where the integrated index almost doubled. A decrease in the efficiency of potential use is observed in Kharkiv and Odesa regions. In general, in all analyzed Ukrainian regions (except for the city of Kyiv), the value of the integrated indicator of the efficiency of the potential of the insurance services sector in 2013 and 2018 did not exceed 0.3. Based on this, one can conclude that the potential of the insurance sector in Ukraine's regions is used by less than a third of its capabilities.

Analysis of changes in indicators characterizing the potential of the insurance services sector in ensuring the socio-economic development of the regions (Table 3) shows that the decrease in the efficiency of the potential of the insurance services sector in Kharkiv region was mainly due to the decrease in the share of profitable enterprises in the insurance services sector (in the analyzed period, it was a record high and amounted to almost 30 p.p.).

A significant increase in the volume of services sold in the Zaporizhzhia region (see Table 1) provided the region with positive dynamics in 10 out of 12 indices characterizing the potential of the insurance services sector in providing the socio-economic development of the region. As a consequence, the financial result increased almost 40 times, and labor productivity - more than 6 times, which contributed to a significant increase in tax payments to the budget - 1.6 times (in monetary terms, it is almost UAH 8 million) and employment growth by more than 25\% (Figure 4).

Such a significant result was achieved due to the fact that insurance activities in the Zaporizhzhia region are carried out by many local insurance companies and their branches, representative offices, departments, and structural units of insur- 
Table 2. Statistical data and results of calculating the integrated index of the efficient use of the insurance services sector potential in ensuring the social and economic development of Ukraine's regions in 2013 and 2018

Source: Calculated by the authors.

\begin{tabular}{|c|c|c|c|c|c|c|c|c|c|c|c|c|c|}
\hline 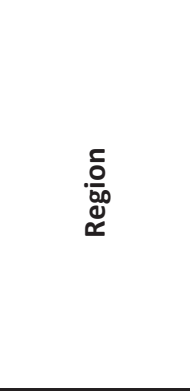 & 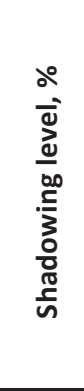 & 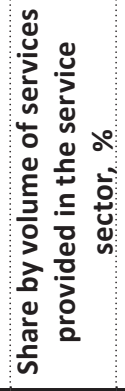 & 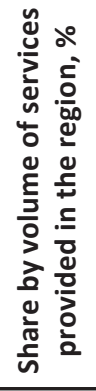 & 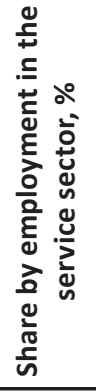 & 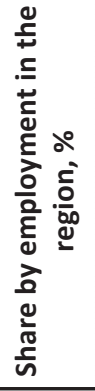 & 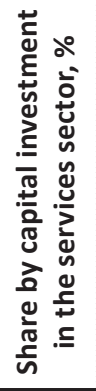 & 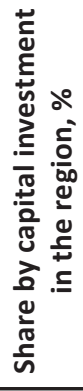 & 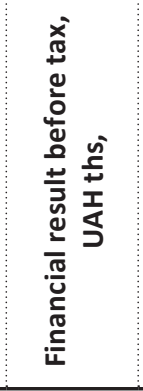 & 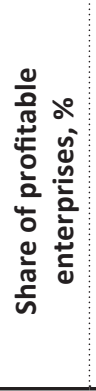 & 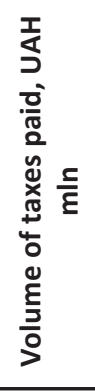 & 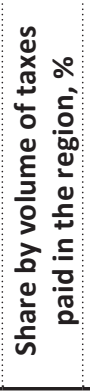 & 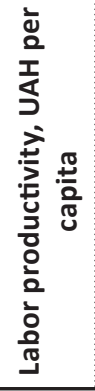 & 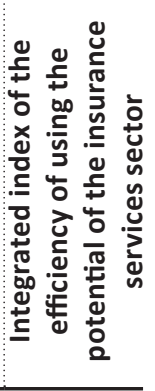 \\
\hline \multicolumn{14}{|c|}{2013} \\
\hline Dnipropetrovsk & 7.64 & 3.94 & 3.98 & 0.04 & 1.49 & 0.01 & 0.16 & 503,520 & 86.7 & 50.38 & 4.02 & 1,951 & 0.239 \\
\hline Zaporizhzhia & 15.61 & 1.91 & 0.63 & 0.14 & 2.36 & 0.06 & 0.36 & $5,737.1$ & 69.2 & 13.24 & 1.06 & 196 & 0.128 \\
\hline Lviv & 25.38 & 0.53 & 0.39 & 0.05 & 1.12 & 0.04 & 0.53 & $-1,766$ & 50 & 12.1 & 0.96 & 257.1 & 0.084 \\
\hline Odesa & 4.56 & 1.54 & 2.21 & 0.03 & 0.86 & 0.01 & 0.2 & 365,739 & 92.3 & 34.6 & 2.76 & 1888 & 0.248 \\
\hline Poltava & 16.65 & 6.44 & 1.67 & 0.03 & 0.36 & 0.02 & 0.11 & $101,568.7$ & 71.4 & 22.51 & 1.79 & 3,415 & 0.233 \\
\hline Kharkiv & 4.87 & 0.58 & 0.43 & 0.03 & 0.86 & 0.06 & 0.87 & 40,633 & 90.5 & 7.73 & 0.62 & 363.5 & 0.188 \\
\hline The city of Kyiv & 16.95 & 11.45 & 75.34 & 1.91 & 83.4 & 0.61 & 94.65 & $4391,201.3$ & 72.3 & 517.62 & 41.27 & 659.7 & 0.854 \\
\hline \multicolumn{14}{|c|}{2018} \\
\hline Dnipropetrovsk & 12.83 & 0.92 & 1.92 & 0.02 & 1.09 & 0.1 & 5 & 319,052 & 77.8 & 30.98 & 1.82 & 2,628 & 0.265 \\
\hline Zaporizhzhia & 19.82 & 6.45 & 3.54 & 0.2 & 4.31 & 0.09 & 0.86 & $226,782.9$ & 63.6 & 20.95 & 1.23 & 1,229 & 0.247 \\
\hline Odesa & 4.62 & 0.35 & 0.85 & 0.03 & 0.98 & 0.02 & 0.59 & 46,207 & 90.9 & 26.05 & 1.53 & 1294 & 0.231 \\
\hline Kharkiv & 19.05 & 0.38 & 0.47 & 0.02 & 0.89 & 0.01 & 0.31 & $-2,608$ & 62.5 & 10.2 & 0.6 & 786.9 & 0.114 \\
\hline The city of Kyiv & 17.30 & 8.91 & 88.62 & 1.41 & 89 & 0.29 & 90.61 & 964,298 & 68.4 & 739.73 & 43.48 & 1490 & 0.882 \\
\hline
\end{tabular}

Table 3. Change in indicators characterizing the potential of the insurance services sector in Ukraine and its regions in 2013-2018

Source: Calculated by the authors.

\begin{tabular}{|c|c|c|c|c|c|c|c|c|c|c|c|c|}
\hline \multirow[b]{2}{*}{ Region } & \multicolumn{9}{|c|}{ Change in share (level) for the period, p.p. } & \multicolumn{3}{|c|}{$\begin{array}{c}\text { Increase (decrease) for the } \\
\text { period, } \%\end{array}$} \\
\hline & $\begin{array}{l}\overline{0} \\
\frac{0}{0} \\
00 \\
\cdot \frac{5}{3} \\
0 \\
\frac{0}{0} \\
\frac{\pi}{n}\end{array}$ & 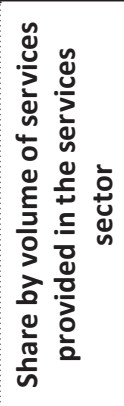 & 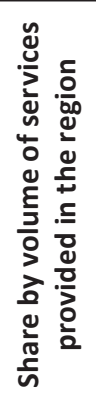 & 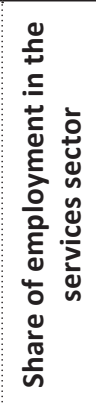 & 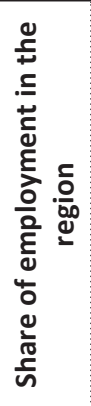 & 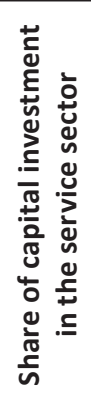 & 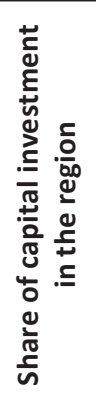 & 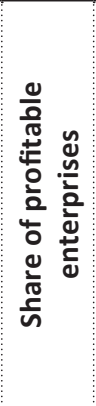 & 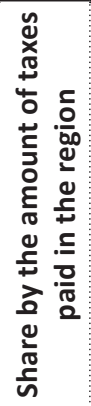 & 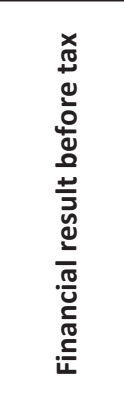 & 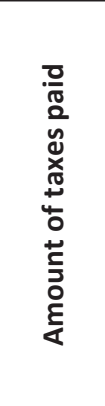 & 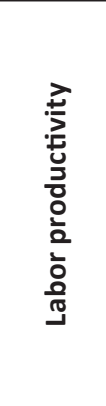 \\
\hline Ukraine & 0.72 & -1.99 & $x$ & -0.03 & $x$ & -0.12 & $x$ & -4.88 & $x$ & -74.58 & 35.65 & 105.06 \\
\hline Dnipropetrovsk & 5.18 & -3.02 & -2.06 & -0.02 & -0.4 & 0.09 & 4.84 & -8.89 & -2.2 & -36.64 & -38.51 & 34.65 \\
\hline Zaporizhzhia & 4.21 & 4.54 & 2.91 & 0.06 & 1.95 & 0.03 & 0.5 & -5.59 & 0.17 & 3852.92 & 58.23 & 526.94 \\
\hline Odesa & 0.06 & -1.19 & -1.36 & 0 & 0.12 & 0.01 & 0.39 & -1.4 & -1.23 & -87.37 & -24.71 & -31.44 \\
\hline Kharkiv & 14.18 & -0.2 & 0.04 & -0.01 & 0.03 & -0.05 & -0.56 & -27.98 & -0.02 & -106.42 & 31.95 & 116.47 \\
\hline The city of Kyiv & 0.36 & -2.54 & 13.28 & -0.5 & 5.69 & -0.32 & -4.04 & -3.93 & 2.21 & -78.04 & 42.91 & 125.79 \\
\hline
\end{tabular}




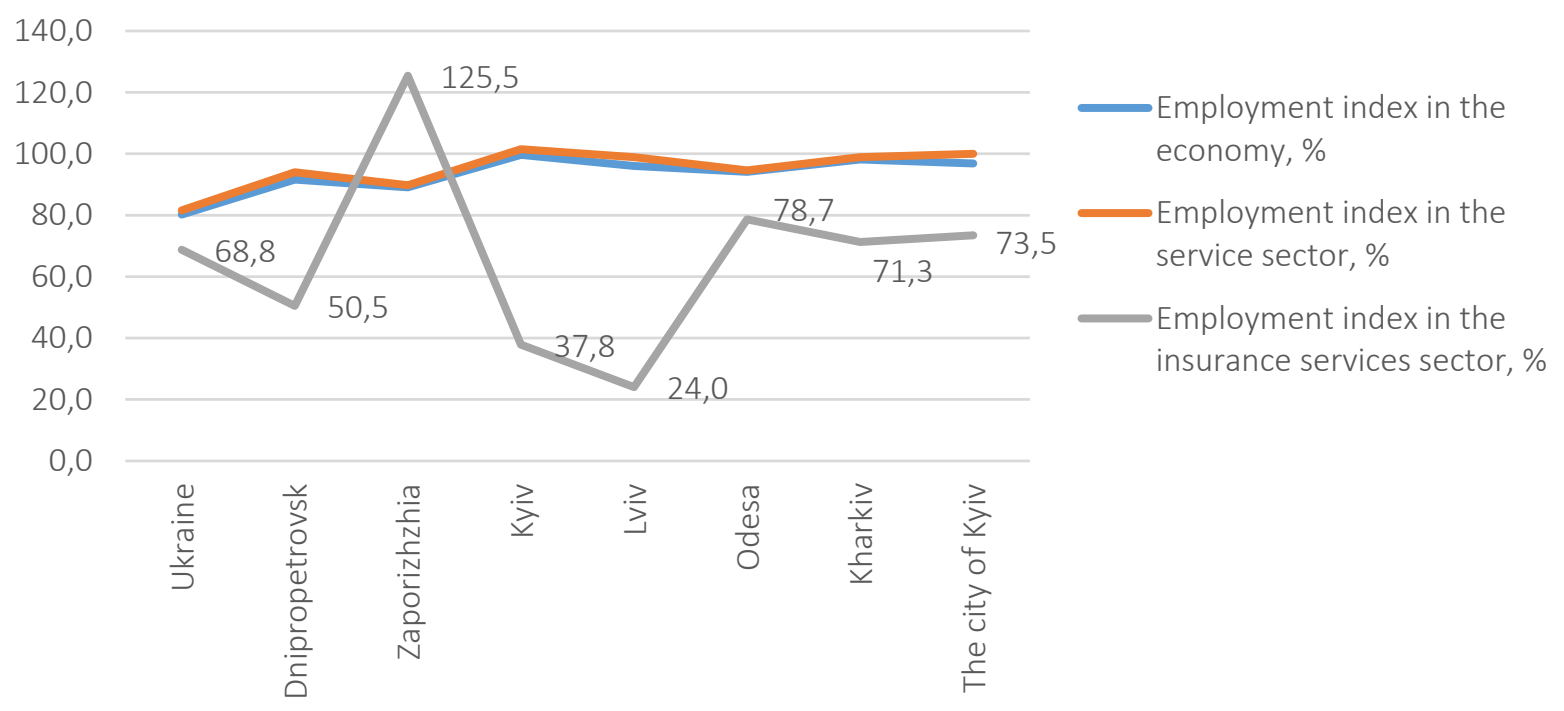

Figure 4. Employment indices in the economy, services and insurance services for 2013-2018

ers from other regions of Ukraine. Partnerships of leading insurance companies with the largest insurance and reinsurance companies in Ukraine and the world allow insuring large property and financial risks of the region's enterprises and investors (Zaporizhzhia Profile, 2017), which ensured such a significant increase in sales of insurance services in the region.

Socio-economic efficiency of the insurance services sector in terms of providing tax revenues to the budget in 2013-2018 is confirmed by the analysis of tax revenues provided by this sector to the Consolidated Budget of Ukraine, including per enterprise (Table 4). Despite the decrease in the number of insurance companies in Ukraine as a whole and in the overwhelming majority of its regions, there is an increase in taxes paid from one enterprise: in 2018, Vinnytsia, Zakarpattia and Donetsk regions became the leaders in this indicator. Meanwhile, the total amount of tax revenues from enterprises in the sector for 2013-2018 decreased by more than 30\% in Dnipropetrovsk, Donetsk and Lviv regions and by more than $60 \%$ in Luhansk and Poltava regions, which is mainly due to a decrease in the number of companies providing insurance services in these regions. In general, in Ukraine for the analyzed period, the insurance sector provided an increase in tax payments by more than $35 \%$, which in monetary terms amounted to almost UAH 450 million.
An assessment of the ratio of the absolute value of growth in tax revenues to the value of growth for 2013-2018 in the volume of services sold shows that in Ukraine as a whole for the analyzed period, $1 \%$ increase in the volume of sold insurance services accounted for an increase in tax payments to the budget in the amount of almost UAH 11 million.

Thus, the analysis shows that the key factor in increasing the socio-economic efficiency of the insurance services sector is an increase in the volume of services provided, which, in turn, is impossible without macroeconomic stability in the country and an increase in living standards. The main obstacles to the effective development of the insurance services sector in Ukraine are: distrust of insurance companies and the financial system as a whole; low paying capacity of the population, including due to high inflation; lack of reliable and profitable instruments for investment for insurance companies and an underdeveloped stock market; low profitability of domestic enterprises; lack of a competent state insurance policy.

The insurance sector, like other service sectors, will change under the influence of the global coronavirus pandemic. According to the pessimistic scenario, for which European market leaders are preparing, COVID-19 could lead to 200\% losses in insurance. Among the external factors that in 
Table 4. Analysis of tax revenues from insurance companies to the Consolidated Budget of Ukraine for 2013-2018 in Ukraine and its regions

Source: Calculated and compiled according to official requests to the State Statistics Service of Ukraine (2019) and the State Tax Service of Ukraine (2019).

\begin{tabular}{|c|c|c|c|c|c|c|c|c|c|}
\hline \multirow[t]{2}{*}{ Region } & \multicolumn{2}{|c|}{$\begin{array}{l}\text { Total taxes paid, UAH } \\
\text { mln }\end{array}$} & \multirow{2}{*}{ 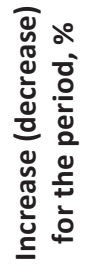 } & \multicolumn{2}{|c|}{$\begin{array}{c}\text { Total number } \\
\text { of enterprises, } \\
\text { unit }\end{array}$} & \multirow{2}{*}{ 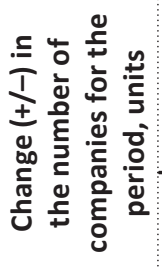 } & \multicolumn{2}{|c|}{$\begin{array}{c}\text { Volume of } \\
\text { taxes paid per } \\
\text { company, UAH } \\
\text { mln }\end{array}$} & \multirow{2}{*}{ 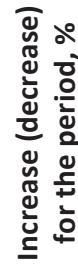 } \\
\hline & 2013 & 2018 & & 2013 & 2018 & & 2013 & 2018 & \\
\hline Ukraine & $1,254.27$ & $1,701.36$ & 35.6 & 469 & 340 & -129 & 2.67 & 5.00 & 87.1 \\
\hline Vinnytsia & 3.42 & 6.24 & 82.5 & 1 & 1 & 0 & 3.42 & 6.24 & 82.5 \\
\hline Dnipropetrovsk & 50.38 & 30.98 & -38.5 & 17 & 11 & -6 & 2.96 & 2.82 & -5.0 \\
\hline Donetsk & 64.27 & 44.5 & -30.8 & 27 & 10 & -17 & 2.38 & 4.45 & 86.9 \\
\hline Zhytomyr & 1.92 & 2.53 & 31.8 & 1 & 1 & 0 & 1.92 & 2.53 & 31.8 \\
\hline Zakarpattia & 2.25 & 6.1 & 171.1 & 2 & 1 & -1 & 1.13 & 6.10 & 442.2 \\
\hline Zaporizhzhia & 13.24 & 20.95 & 58.2 & 13 & 11 & -2 & 1.02 & 1.90 & 87.0 \\
\hline Ivano-Frankivsk & 6.15 & 16.1 & 161.8 & 3 & 5 & 2 & 2.05 & 3.22 & 57.1 \\
\hline Kyiv & 13.66 & 13.59 & -0.5 & 11 & 5 & -6 & 1.24 & 2.72 & 118.9 \\
\hline Luhansk & 6.86 & 0.93 & -86.4 & 4 & 2 & -2 & 1.72 & 0.47 & -72.9 \\
\hline Lviv & 12.1 & 7.8 & -35.5 & 8 & 5 & -3 & 1.51 & 1.56 & 3.1 \\
\hline Mykolaiv & 2.45 & 2.65 & 8.2 & 3 & 2 & -1 & 0.82 & 1.33 & 62.2 \\
\hline Odesa & 34.6 & 26.05 & -24.7 & 15 & 11 & -4 & 2.31 & 2.37 & 2.7 \\
\hline Poltava & 22.51 & 8.57 & -61.9 & 7 & 3 & -4 & 3.22 & 2.86 & -11.2 \\
\hline Kharkiv & 7.73 & 10.2 & 32.0 & 21 & 16 & -5 & 0.37 & 0.64 & 73.2 \\
\hline Kherson & 1.62 & 2.38 & 46.9 & 1 & 3 & 2 & 1.62 & 0.79 & -51.0 \\
\hline Cherkasy & 2.04 & 4.05 & 98.5 & 2 & 2 & 0 & 1.02 & 2.03 & 98.5 \\
\hline The city of Kyiv & 517.62 & 739.73 & 42.9 & 321 & 251 & -70 & 1.61 & 2.95 & 82.8 \\
\hline
\end{tabular}

the long term will reduce the potential of the insurance services sector are the following (Moroz \& Horokhovskyi, 2020):

- increase in the price of reinsurance;

- downgrading of financial stability/reliability ratings of reinsurers;

- introduction of additional exceptions and restrictions in reinsurance;

- reduced activity or termination of work with small markets or emerging markets, if financial investments are required to enter the market.

It can be concluded that the influence of these factors on the development of the domestic insurance market will be insignificant, given the small volume of risk reinsurance for non-residents (Zhabynets, 2020). Therefore, the rise in prices on the world reinsurance market will prac- tically not affect the cost of most insurance services in Ukraine, and therefore, their purchase by consumers.

The most negative impact of the global coronavirus pandemic will be mainly due to internal factors and their consequences, which is confirmed by studies of other scientists (Dankiewicz et al., 2020; Polinkevych et al., 2021). A drop in GDP and a decline in business activity will have a significant impact on the solvency of legal entities and individuals, and hence on sales of insurance services. As a result of the quarantine, income from the amount of collected insurance premiums in many insurance companies will sharply decrease and the volume of insurance reserves will decrease, which may affect the solvency of insurance companies and their default on obligations under insurance contracts. Massive non-payments in the insurance sector will increase the already significant distrust of insurers, and in the context of transfer of powers to regulate the insurance market to the NBU, which will check the compli- 
ance of insurance companies with financial standards this year, will led to the liquidation of many of them. According to experts, in the short term, the current situation (2020-2021) will resemble the situation in the banking sector in 2014-2015, and in the long term (2022-2023), after reformatting the insurance market, consumers will receive much better services, however with a possible increase in their value due to the recovery of the market (Moroz \& Horokhovskyi, 2020).

In modern conditions of global economic changes in the world financial market and Ukraine's insurance market, in order to activate sales of insurance services and increase the efficiency of the domestic insurance sector potential in the context of social and economic development of regions, it is necessary to implement a number of measures in the following main areas: general economic recovery, ensuring macroeconomic stability and low inflation; strengthening insurance supervision and regulation, in particular with regard to licensing standards, formation of insurance reserves, capital structure, withdrawal of insurers from the market; ensuring the transparency in the activities of market participants and its attractiveness to investors; raising the financial, including insurance, literacy of the population and protecting their rights as consumers of insurance services.

\section{CONCLUSION}

The analysis showed an increase in the efficiency of using the potential of the insurance services sector in providing socio-economic development in three of the five analyzed Ukrainian regions. In terms of the growth in the integrated index of the efficient use of the insurance services sector potential, the leader is the Zaporizhzhia region, where, as a result of a significant increase in the volume of services sold for the period 2013-2018, positive dynamics was provided for most indicators characterizing the potential of the insurance sector in ensuring socio-economic development, including an increase in tax revenues to the budget 1.6 times and employment - by 25\%. In general, in Ukraine for the analyzed period, $1 \%$ increase in the volume of sold insurance services accounted for an increase in tax payments to the budget in the amount of almost 11 million UAH. Thus, it has been proven that an increase in the volume of services rendered is a key factor in increasing the socio-economic efficiency of the insurance sector.

The proposed measures to increase the efficiency of using the domestic insurance sector potential in providing the social and economic development of Ukraine's regions will contribute to the activation of sales of insurance services, and, consequently, an increase in the volume of their sales. This will enhance the socio-economic effects of the development of the insurance sector, including towards increasing the competitiveness of insurance enterprises in the global financial market and proper performance by them not only the function of protecting the population and business structures from unforeseen events (risks), but also the function of a supplier of long-term investment resources to finance priority sectors of the national economy. Given that the calculation results showed an increase in the level of shadowing of the insurance services sector in Ukraine, the prospects for further research will be associated with the development of measures for its de-shadowing.

\section{AUTHOR CONTRIBUTIONS}

Conceptualization: Mariana Melnyk.

Data curation: Olha Zhabynets.

Formal analysis: Olha Zhabynets, Volodymyr Orlov.

Investigation: Mariana Melnyk, Olha Zhabynets, Ivanna Myshchyshyn.

Methodology: Mariana Melnyk, Ivanna Myshchyshyn.

Project administration: Mariana Melnyk, Ivanna Myshchyshyn.

Supervision: Mariana Melnyk.

Validation: Mariana Melnyk, Olha Zhabynets, Ivanna Myshchyshyn, Volodymyr Orlov. 
Visualization: Mariana Melnyk, Olha Zhabynets, Ivanna Myshchyshyn, Volodymyr Orlov. Writing - original draft: Olha Zhabynets, Volodymyr Orlov.

Writing - review \& editing: Mariana Melnyk.

\section{REFERENCES}

1. Arkhipov, A., Bazanov, A., Belozerov, S., Boldyreva, N., Galkina, E., Gamankova, O., Gvarliani, T., Grebenshchikov, E., Domnina, O., Dymnich, O., Zelenitsa, I., Kalayda, S., Kirillova, N., Komarova, N., Kudriavtsev, A., Kuznetsova, N., Logvinova, I., Nosanenko, G., Obukhov, I., ... \& Velickiene, M. (2017). Strakhovanie i upravlenie riskami: problemy i perspektivy [Insurance and risk management: problems and perspectives]. Moscow: Prospekt. (In Russian).

2. ASKA. (n.d.). Official site. Istoriya ASKA [History of ASKA]. (In Ukrainian). Retrieved from https://aska.ua/ua/about/history

3. Baranovskyi, O., Levchenko, V., \& Polishchuk, Y. (2015). Non-bank financial institutions' activity under force majeure. Actual Problems of Economics, 168(6), 332-340. Retrieved from https://search.proquest.com/openview/29ab3040bb 1dc40304b965c8c9e44797/1?pqorigsite $=$ gscholar $\& \mathrm{cbl}=2035679$

4. Boyko, A., \& Roienko, V. (2015). Kryterii otsiniuvannia sfery vykorystannia strakhovykh kompanii v skhemnykh operatsiiakh [Criteria for evaluating the scope of use of insurance companies in scheme operations]. Finansovyi prostir - Financial Space, 1(17), 51-54. (In Ukrainian). Retrieved from http://nbuv.gov.ua/UJRN/ Fin_pr_2015_1_8

5. Dankiewicz, R., Tworzydło, D., \& Ostrowska-Dankiewicz, A. (2020). Distribution of services within the call center and COVID 19 - a case study. WSEAS Transactions on Business and Economics, 17, 921-932. https://doi. org/10.37394/23207.2020.17.90

6. Domański, R., Pająk, L., Smoleń, D., \& Sokoliński, O. (2020). Ubezpieczenia dla MSP niewykorzystany potencjał czy ryzykowna gra. Miesięcznik ubez- pieczeniowy, 3, 21-23. Retrieved from https://www.mckinsey.com/ $\mathrm{pl} / \sim$ media/McKinsey/Locations/ Europe\%20and\%20Middle\%20 East/Polska/Raporty/Ubezpieczenia\%20MSP/Miesiecznik\%20 Ubezpieczeniowy_Ubezpieczenia\%20MSP.pdf

7. Gamankova, O. (2009). Rynok strakhovykh posluh Ukrainy: teoriia, metodolohiia, praktyka [The market of insurance services of Ukraine: theory, methodology, practice] (283 p.). Kyiv: KNEU. (In Ukrainian).

8. Grzebyk, M., \& Stec, M. (2014) Social and economic development of Ukraine in comparison to European Union member states: Statistical evaluation. Economic Annals-XXI, 5-6, 17-21. Retrieved from http://nbuv.gov.ua/UJRN/ecchado_2014_5-6_5

9. Hepfer, B., Wilde, J., \& Wilson, R. (2016). Taking Shadow Insurance Out of the Shadows: Regulatory Arbitrage, Taxes, and Capital. Retrieved from https://uwaterloo. $\mathrm{ca} /$ school-of-accounting-and-finance/sites/ca.school-of-accounting-and-finance/files/uploads/ files/session_4_hww.pdf

10. Ionin, M. (2017). Rynkovi chynnyky vplyvu na konkurentnyi potentsial strakhovoi kompanii [Market factors of influence on the competitive potential of the insurance company]. Ekonomika i orhanizatsiia upravlinnia - Economics and organization of management, 3(27), 116-126. (In Ukrainian).

11. Jarrayaa, B., \& Bourib, A. (2013). Efficiency concept and investigations in insurance industry: A survey. Management Science Letters, 3, 39-54.

12. Kaigorodova, G., Mustafina, A., Pyrkova, G., Mamchur, R., Zelenitsa, I., \& Kul, T. (2020). Growth Factors of Insurance Interests of Russian Citizens. 36th
International Business Information Management Association Conference, IBIMA. Conference on 4-5 November 2020 Granada, Spain. Retrieved from https://ibima.org/ accepted-paper/growth-factorsof-insurance-interests-of-russiancitizens/

13. Koijen, R., \& Yogo, M. (2016). Shadow Insurance. ECONOMETRICA, 84(3), 1265-1287. https:// doi.org/10.3982/ECTA12401

14. Kovalenko, Yu., \& Litvin, Ya. (2019). Finansovo-investytsiinyi potentsial strakhovykh kompanii v Ukraini [Financial and investment potential insurance companies in Ukraine]. Zbirnyk naukovykh prats Universytetu derzhavnoi fiskalnoi sluzhby Ukrainy - Collection of scientific works of the University of the State Fiscal Service of Ukraine, 1, 109-124. (In Ukrainian).

15. Kozmenko, O., \& Mospanova, Y. (2016). Priority directions of improvement of state of pension coverage in Ukraine. Investment Management and Financial Innovations, 13(3-2), 300-310. https:// doi.org/10.21511/imfi.13(32). 2016.02

16. Kozmenko, O., \& Roienko, V. (2013). Evaluation and use of indicators of insurance companies' investment activities. Investment Management and Financial Innovations, 10(3), 98-105. Retrieved from https://businessperspectives. org/media/zoo/applications/publishing/templates/article/assets/js/ pdfjs/web/5373

17. Kravets, A. (2007). Sposoby realizatsii «skhemnoho» strakhuvannia na strakhovomu rynku Ukrainy [Ways to implement "scheme" insurance in the insurance market of Ukraine]. Menedzhment ta pidpriemnytstvo Ukrainy: etapy stanovlennia i problemy rozvytku - Management and Entrepreneurship of Ukraine: the 
stages of formation and problems of development, 606, 192-197. (In Ukrainian).

18. Legislation of Ukraine. (2010). Podatkovyi kodeks Ukrainy [Tax Code of Ukraine]. (In Ukrainian). Retrieved from https://zakon.rada. gov.ua/laws/show/2755-17

19. Legislation of Ukraine. (2020). Proiekt Zakonu pro vnesennia zmin do Zakonu Ukrainy "Pro turyzm" ta deiakykh inshykh zakonodavchykh aktiv shchodo osnovnykh zasad rozvytku turyzmu [Draft Law on Amendments to the Law of Ukraine "On Tourism" and some other legislative acts on the basic principles of tourism development]. (In Ukrainian). Retrieved from http://w1.c1.rada.gov.ua/pls/ zweb2/webproc4_1?pf3511=70072

20. Levchenko, V., Boyko, A., Bozhenko, V., \& Mynenko, S. (2019). Money laundering risk in developing and transitive economies: Analysis of cyclic component of time series. Business: Theory and Practice, 20, 492-508. https://doi. org/10.3846/btp.2019.46

21. Likhonosova, G. (2020). Formation of the dynamic potential of Ukraine's insurance market. Time Description of Economic Reforms, 1(37), 49-56. (In Ukrainian). https://doi.org/10.32620/ cher.2020.1.07

22. Miller, T., Kim, A., \& Roberts, J. (2018). Index of Economic Freedom. Heritage Foundation. Retrieved from https://www.heritage.org/ index/pdf/2018/book/index_2018. pdf

23. Minfin. (2019). Strakhovyi rynok Ukrainy pokrashchyv pozytsii u svitovomu reitynhu [Ukraine's insurance market has improved its position in the world rankings]. (In Ukrainian). Retrieved from https://minfin.com.ua/ ua/2019/07/10/38369093/

24. Ministry for Development of Economy, Trade and Agriculture of Ukraine. (2009). Metodychni rekomendatsii rozrakhunku rivnia tiniovoi ekonomiky [Methodological recommendations for calculating the level of the shadow econo$m y$ ]. (In Ukrainian). Retrieved from https://www.me.gov.ua/
LegislativeActs/Detail?lang=ukUA\&id $=4 b b 297 \mathrm{a} 0-\mathrm{c} 900-404 \mathrm{f}-$ 8c6f-5f76f18b 1503

25. Ministry for Development of Economy, Trade and Agriculture of Ukraine. (2020). Tendentsii tinovoi ekonomiky $v$ Ukraini u sichni-berezni 2020 roku. [Trends in the shadow economy in Ukraine in January-March 2020]. (In Ukrainian). Retrieved from https://www.me.gov.ua/ Documents/List?lang=ukUA\&id=e384c5a7-6533-4ab6b56f-50e5243eb15a\&tag=Tendent siiTinovoiEkonomiki

26. Moroz, A., \& Horokhovskyi, D. (2020). Karantyn 2020: Shcho my pobachymo na strakhovomu rynku v 2020-2021 rokakh: prohnoz vid Broker's Insurance Group [Quarantine 2020: What we will see in the insurance market in 2020-2021: forecast from Broker's Insurance Group]. (In Ukrainian). Retrieved from http://uaprom. info/digest/24235-karantin2020shho-mi-pobachimo-strahovomurinku-2020-2021-rokah-prognozvid-brokers-insurance-group.html

27. National Bank of Ukraine. (2020). Bila knyha. Maibutnie rehuliuvannia rynku strakhuvannia $v$ Ukraini [White book. Future regulation of the insurance market in Ukraine]. (In Ukrainian). Retrieved from https://bank.gov.ua/ua/news/all/ bila-kniga-maybutnye-regulyuvannya-rinku-strahuvannya

28. Płonka, M., Jedynak, T., \& Trynchuk, V. (2020). Retirement behavior strategies: the attitudes of students from Poland and Ukraine towards the old-age risk. Problems and Perspectives in Management, 18(2), 350365. http://dx.doi.org/10.21511/ ppm.18(2).2020.29

29. Polinkevych, O., Khovrak, I., Trynchuk, V., Klapkiv, Y., \& Volynets, I. (2021). Business Risk Management in Times of Crises and Pandemics. Montenegrin Journal of Economics, 17(3), 117128.

30. Pyrkova, G., Alyakina, D., Kaigorodova, G., Mustafina, A., \& Trynchuk, V. (2018). Investment activity of insurers and the state economic growth. Montenegrin Journal of Economics, 14(4), 109-123. http://dx.doi. org/10.14254/1800-5845/2018.144.8

31. Remeikiene, R., Gaspareniene, L., \& Heikkila, M. (2017). Evaluation of the impact of shadow economy determinants: Ukrainian case. Intellectual Economics, 10, 108-113.

32. Romanovska, Y., Kaminska, A., \& Bozhok, M. (2020). Financial potential of the Ukrainian insurance market. Naukovyi visnyk Mizhnarodnoho humanitarnoho universytetu - Scientific Bulletin of the International Humanities University, 184-190. (In Ukrainian). https://doi.org/10.32841/24132675/2020-42-32

33. Samorodov, B., Azarenkova, G., \& Golovko, O. (2018). Improving the business process by finding additional resources needed to increase financial potential of insurance company. Collection of scientific works "Financial and credit activities: problems of theory and practice", 1(24), 250-257.

34. Schwab, K. (Ed.) (2019). The Global Competitiveness Report 2017-2018. Retrieved from http://www3.weforum.org/docs/ GCR2017-2018/05FullReport/The GlobalCompetitivenessReport201 7\%E2\%80\%932018.pdf

35. Schwarcz, D. (2015). The Risks of Shadow Insurance. Georgia Law Review, 50(163), 163-211. Retrieved from https://ssrn.com/ abstract $=2630176$

36. Shumska, S., \& Nezhyvenko, O. (2013). Shadow economy in Ukraine: methodology and evaluation. Actual problems of economics - Aktualni problemy ekonomiky, 10(148), 74-83.

37. State Statistics Service of Ukraine. (2019). Derzhavna sluzhba statystyky Ukrainy [State Statistics Service of Ukraine]. Ofitsiynyi sait - Official site. (In Ukrainian). Retrieved from http://www. ukrstat.gov.ua/

38. State Tax Service of Ukraine. (2019). Ofitsiynyi sait - Official site. (In Ukrainian). Retrieved from https://tax.gov.ua/ 
39. Transparency International. (2019). Corruption Perceptions Index 2018. Retrieved from https:// images.transparencycdn.org/images/CPI_2018_Executive_Summary_EN.pdf

40. USAID. (2019). Nederzhavne pensiine zabezpechennia v Ukraini: otsinka ta rekomendatsii [Nonstate pension provision in Ukraine: assessment and recommendations]. USAID Financial Sector Transformation Project. (In Ukrainian). Retrieved from http://www.fst-ua. info/wp-content/uploads/2019/07/ Voluntary_Private_Pensions_in_ Ukraine-Assessment_jul2019_ ua.pdf

41. Vasylenko, A. (2012). Podatkove stymuliuvannia rozvytku strakhuvannia [Tax incentives for insurance development]. Visnyk KNTEU - KNTEU Bulletin, 4, 3446. (In Ukrainian)

42. Vilenchuk, O. (2017). Otsinka potentsialu rozvytku strakhuvan- nia silskohospodarskoi produktsii v Ukraini [Assessment of the potential for the development of agricultural insurance in Ukraine]. Ekonomika APK - Economics of agro-industrial complex, 8, 56-64. (In Ukrainian).

43. Vinnychuk, I., \& Ziukov, S. (2013). Shadow economy in Ukraine: modelling and analysis. Business Systems \& Economics, 3(2), 141-152. https://doi.org/10.13165/ VSE-13-3-2-01

44. Vucetich, A., Perry, R., \& Dean, R. (2014). The insurance sector and economic stability. Reserve Bank of New Zealand: Bulletin, 77(3). Retrieved from https:// www.rbnz.govt.nz/-/media/ReserveBank/Files/Publications/ Bulletins/2014/2014sep77-3.pdf

45. World Bank. (2019). Doing Business 2019. A World Bank Group Flagship Report. Retrieved from http://www.worldbank.org/content/dam/doingBusiness/media/
Annual-Reports/English/DB2019report_web-version.pdf

46. Zaporizhzhia Profile. (2017). Dodatok 1 do Stratehii rozvytku mista Zaporizhzhia do 2028 roku [Annex 1 to the Strategy of development of the city of Zaporizhia until 2028]. (In Ukrainian). Retrieved from https://zp.gov.ua/upload/editor/ dodatok_1__e.pdf

47. Zhabynets, O. (2014). Data protection and information security of insurance companies. Economic Annals-XXI, 7-8(2), 3235. (In Ukrainian).

48. Zhabynets, O. (2020). Tinizatsiia finansovykh potokiv na rynku strakhuvannia: osnovni skhemy ta instrumenty realizatsii [Shadowing the financial flows in the insurance market: the main schemes and instruments for implementation]. Biznes Inform - Business Inform, 5, 356-363. (In Ukrainian). https://doi.org/10.32983/22224459-2020-5-356-363 


\section{APPENDIX A}

Table A1. Initial data and results of calculating the level of shadowing of the insurance sector in Ukraine and its regions in 2013 and 2018

Source: Compiled and calculated according to the official requests to the State Statistics Service of Ukraine (2019).

\begin{tabular}{|c|c|c|c|c|c|c|c|c|c|c|c|c|}
\hline \multirow[b]{2}{*}{ Region } & \multicolumn{3}{|c|}{$\begin{array}{c}\text { Number of } \\
\text { enterprises, units }\end{array}$} & \multirow{2}{*}{ 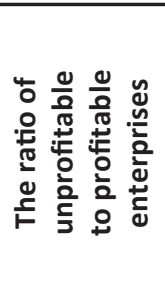 } & \multirow{2}{*}{$\begin{array}{c}\text { Financial result } \\
\text { of profitable } \\
\text { enterprises } \\
\text { before tax } \\
\text { (profit), UAH } \\
\text { ths. }\end{array}$} & \multirow{2}{*}{$\begin{array}{c}\text { Financial result } \\
\text { of unprofitable } \\
\text { enterprises } \\
\text { before tax } \\
\text { (loss), UAH ths. }\end{array}$} & \multirow{2}{*}{$\begin{array}{l}\text { Attributable } \\
\text { profit of } \\
\text { unprofitable } \\
\text { enterprises, } \\
\text { UAH, ths. }\end{array}$} & \multirow{2}{*}{$\begin{array}{c}\text { Shadow } \\
\text { income, UAH } \\
\text { ths. }\end{array}$} & \multirow[b]{2}{*}{$\begin{array}{l}\text { GVA*, UAH } \\
\text { ths. }\end{array}$} & \multirow{2}{*}{$\begin{array}{l}\text { Marginal } \\
\text { minimum } \\
\text { level of the } \\
\text { shadow } \\
\text { economy, \% } \\
\text { of GVA }\end{array}$} & \multirow{2}{*}{$\begin{array}{l}\text { Marginal } \\
\text { maximum } \\
\text { level of the } \\
\text { shadow } \\
\text { economy, } \\
\% \text { of GVA }\end{array}$} & \multirow{2}{*}{$\begin{array}{c}\text { Shadow } \\
\text { economy } \\
\text { level } \\
\text { (mean), \% } \\
\text { of GVA }\end{array}$} \\
\hline & సٓ & $\begin{array}{l}\frac{0}{0} \\
\frac{0}{20} \\
\frac{7}{0} \\
\frac{0}{2} \\
\frac{0}{5}\end{array}$ & $\begin{array}{l}\frac{0}{0} \\
\frac{0}{0} \\
\frac{0}{0} \\
\frac{0}{0}\end{array}$ & & & & & & & & & \\
\hline \multicolumn{13}{|c|}{2013} \\
\hline Ukraine & 469 & 123 & 346 & 0.4 & $7,344,875.5$ & $1,182,336.7$ & $2,605,507.9$ & $3,787,844.6$ & $67,531,000$ & 5.61 & 26.19 & 15.90 \\
\hline Dnipropetrovsk & 17 & 2 & 15 & 0.2 & $519,711.0$ & $16,191.0$ & $79,953.2$ & $96,144.2$ & $4,917,000$ & 1.96 & 13.33 & 7.64 \\
\hline Donetsk & 27 & 10 & 17 & 0.6 & $920,762.1$ & $694,019.6$ & $517,928.7$ & $1,211,948.3$ & $4,673,000$ & 25.94 & 36.00 & 30.97 \\
\hline Zaporizhzhia & 13 & 4 & 9 & 0.4 & $8,238.5$ & $2,501.4$ & $3,661.5$ & $6,162.9$ & $1,389,000$ & 0.44 & 30.77 & 15.61 \\
\hline Luhansk & 4 & 1 & 3 & 0.3 & $12,769.0$ & $3,196.0$ & $4,256.3$ & $7,452.3$ & $1,188,000$ & 0.63 & 25.00 & 12.81 \\
\hline Lviv & 8 & 4 & 4 & 1.0 & $7,297.0$ & $9,063.0$ & $7,297.0$ & $16,360.0$ & $2,138,000$ & 0.77 & 50.00 & 25.38 \\
\hline Odesa & 15 & 1 & 14 & 0.1 & $365,747.0$ & 8.0 & $30,477.6$ & $30,485.6$ & $2,130,000$ & 1.43 & 7.69 & 4.56 \\
\hline Poltava & 7 & 2 & 5 & 0.4 & $109,060.0$ & $7,491.3$ & $43,623.1$ & $51,114.4$ & $1,081,000$ & 4.73 & 28.57 & 16.65 \\
\hline Kharkiv & 21 & 2 & 19 & 0.1 & $43,200.0$ & $2,567.0$ & $4,547.5$ & $7,114.5$ & $3,340,000$ & 0.21 & 9.52 & 4.87 \\
\hline The city of Kyiv & 321 & 89 & 232 & 0.4 & $4,776,029.2$ & $384,827.9$ & $1,831,922.4$ & $2,216,750.3$ & $35,927,000$ & 6.17 & 27.72 & 16.95 \\
\hline \multicolumn{13}{|c|}{2018} \\
\hline Ukraine & 340 & 106 & 234 & 0.5 & $2,520,792.2$ & $954,129.4$ & $1,135,492.0$ & $2,089,621.4$ & $95,621,000$ & 2.19 & 31.06 & 16.62 \\
\hline Dnipropetrovsk & 11 & 2 & 9 & 0.3 & $451,153.0$ & $132,101.0$ & $128,900.9$ & $261,001.9$ & $7,604,000$ & 3.43 & 22.22 & 12.83 \\
\hline Zaporizhzhia & 11 & 4 & 7 & 0.6 & $231,682.9$ & $4,900.0$ & $132,390.2$ & $137,290.2$ & $4,187,000$ & 3.28 & 36.36 & 19.82 \\
\hline Lviv & 5 & 3 & 2 & 1.5 & $1,431.0$ & $1,168.0$ & $2,146.5$ & $3,314.5$ & $3,620,000$ & 0.09 & 60.00 & 30.05 \\
\hline Odesa & 11 & 1 & 10 & 0.1 & $46,372.0$ & 165.0 & $4,637.2$ & $4,802.2$ & $3,070,000$ & 0.16 & 9.09 & 4.62 \\
\hline Kharkiv & 16 & 6 & 10 & 0.6 & $13,156.0$ & $15,764.0$ & $7,893.6$ & $23,657.6$ & $3,984,000$ & 0.59 & 37.50 & 19.05 \\
\hline The city of Kyiv & 251 & 79 & 172 & 0.5 & $1,675,561.4$ & $711,263.4$ & $775,722.9$ & $1,486,986.3$ & $50,277,000$ & 2.96 & 31.65 & 17.30 \\
\hline
\end{tabular}

Note: * For calculations, GVA for Financial and Insurance Activities for respective years is taken. 